\title{
APLIKASI GAME WIN START LA BERBASIS ANDROID
} Roiduddin Al Adib ${ }^{1)}$, Nurul Fuad ${ }^{2)}$, Retno wardhani ${ }^{3)}$

\author{
${ }^{1)}$ Mahasiswa Program Studi Teknik Informatika Universitas Islam Lamongan \\ ${ }^{2)}$ Dosen Fakultas Teknik Prodi Teknik Informatika Universitas Islam Lamongan \\ ${ }^{3)}$ Dosen Fakultas Teknik Prodi Teknik Informatika Universitas Islam Lamongan
}

Email : kangadiivee@gmail.coml, nurulfuad23@gmail.com², 'retzno@yahoo.com³

\begin{abstract}
ABSTRAK
Game merupakan salah satu hiburan yang seru dan menarik untuk mengisi waktu luang atau menghilangkan kejenuhan di saat menunggu, beragam game atau permainan telah banyak dibuat dan diproduksi secara gratis ataupun berbayar. Mulai dari game yang bertema asah otak, olahraga, hingga petualangan. Sebuah game berbasis android dapat memberi hiburan bagi pemainnya. Tujuan dari penelitian ini adalah merancang dan membangun sebuah game yang dapat dimainkan untuk mengisi waktu luang dan menghilangkan kejenuhan di saat menunggu. Metode yang digunakan dalam merancang dan membangun game ini adalah Metode "Pengembangan Multimedia". Tahapan dalam proses penelitian ini yaitu Tahap Concept, Design, Material Collection, dan Testing. Dengan menggunakan bahasa pemograman Unity Game Engine dan Android SDK, akan menghasilkan sebuah game android berjudul "Aplikasi Game Win Start Berbasis Android" untuk menambah wawasan dalam pembuatan game dengan tema asah otak dan menerapkan pelajaran kecerdasan buatan (Game Playing) dengan algoritma greedy, menggunakan grafik 2D dan dirancang untuk single player.
\end{abstract}

Kata Kunci : Labirin, Game, Android.

\begin{abstract}
Game is one of the entertainment that is fun and interesting way to spend leisure time or relieve boredom at the time of waiting, a variety of games or game has been created and produced many free or paid. Starting from a brain teaser game theme, sports, to adventure. An android based games can provide entertainment for players. The purpose of this study was to design and build a game that can be played in your spare time and eliminate boredom when waiting. The method used in designing and building this game is the method of "Multimedia Development". Stages in the process of this study is Phase Concept, Design, Material Collection and Testing. By using the Unity Game Engine programming language and Android SDK, will produce an android game titled "Application-Based Android Game Win Start" to increase knowledge in making games with the theme of brain teasers and applying the lessons of artificial intelligence (Playing Game) with a greedy algorithm, uses 2D graphics and is designed for a single player.
\end{abstract}

Keywords: Maze, Game, Android.

\section{PENDAHULUAN \\ Latar Belakang}

Game merupakan sebuah bentuk hiburan yang banyak digemari oleh kalangan anak-anak, remaja bahkan dewasa. Bagi sebagian orang, game dijadikan sebagai penyegar pikiran dan untuk menghilangkan kejenuhan. Banyak sekali game yang menggambarkan dunia seperti kehidupan nyata. Untuk membuat game yang menarik mendekati kehidupan nyata perlu ditunjang oleh kemampuan untuk menciptakan karakter-karakter dalam game yang mampu merespon lingkungannya.

Perkembangan yang mulai marak ditemui saat ini adalah game berbasis android. Karena sistem operasi android 
sangat mudah digunakan dan dapat diakses oleh semua kalangan. Keuntungan bagi developer, terutama developer pemula ialah mudahnya penjualan aplikasi hasil karya mereka ke seluruh penjuru dunia dengan sistem pemasaran terpusat. Aplikasi game menempati urutan 8 dari 10 peringkat tertinggi aplikasi gratis android. Dari data tersebut bisa ditarik kesimpulan bahwa game adalah jenis aplikasi paling diminati dan perlu adanya game baru untuk menambah variasi game di android.

Tujuan penelitian ini adalah :

1. membangun aplikasi game Win Start La pada mobile smartphone android bergenre Adventure dengan menggunakan pendekatan Artificial Intellegent pada musuh dalam labirin area.

2. Untuk mengetahui respon pengguna terhadapgame win start l.a

Adapun manfaat dari dibangunnya Game Win Start La ini adalah:

1. Menjadikan game edukasi sebagai media pembelajaran yang interaktif dan mampu menarik perhatian serta minat pemain game dari segala usia.

2. Menciptakan game edukasi yang menarik yang dapat meningkatkan minat, kecerdasan, kreatifitas dan pengetahuan tentang kondisi geografis kota lamongan untuk pengguna game.

\section{TINJAUAN PUSTAKA \\ Pengertian Game}

Game adalah kebutuhan dasar setiap manusia untuk menikmati hidup dan sebagai media pembelajaran. Berikut ini adalah definisi game :

Menurut

wikipedia

(http://en.wikipedia.org), game adalah aktifitas yang melibatkan satu atau lebih pemain.Game dapat pula diartikan sebagai tujuan yang ingin dicapai pemain atau sekumpulan aturan yang menandakan apa yang dilakukan pemain dan yang tidak dapat dilakukan.

\section{Pengertian Anroid}

Android adalah sebuah sistem operasi mobile yang berbasiskan pada versi modifikasi dari Linux. Pertama kali sistem operasi ini dikembangkan oleh perusahaan Android.Inc. Nama perusahaan inilah yang pada akhirnya digunakan pada proyek sistem operasi mobile tersebut, yaitu sistem operasi Android.

\section{Game Labirin 2D}

Permainan game Labirin adalah suatu jenis permainan yang terlihat sederhana namun mempunyai banyak teka-teki logika untuk menyelesaikannya. Dimana tampilannya dua dimensi (panjang dan lebar), hanya dapat dilihat dari satu sudut perspektif. Aplikasi permainan labirin 2D ini bersifat single-user. Tingkatan atau level bermain pada game labirin 2D ini terletak pada penelusuran rute perjalanan yang harus dilalui oleh seorang pemain dalam menemukan jalur mana yang tepat. Object digerakkan dengan menggunakan virtual stick dengan mendrag tombol yang ada di tengah stick ke arah atas untuk menggerakan player ke atas, ke arah bawah untuk menggerakan player ke bawah, ke arah kiri untuk menggerakan ke kiri, dan ke arah kanan untuk menggerakan ke kanan. Hal ini dilakukan sampai object menemukan jalan

\section{Game Win Start La}

Permainan Win Start La adalah sebuah permainan beraliran labirin (maze) dengan konsep yang sangat sederhana : diberikan suatu labirin dengan berbagai dinding rintangan di dalamnya, suatu titik yang merupakan posisi awal munculnya karakter Win Start La, titik-titik yang harus dilewati, dan - yang paling menarik beberapa musuh yang harus dihindari.

Objektif permainan Win Start La adalah pemain diharuskan menggerakkan karakter Win Start La menyusuri labirin tersebut melewati semua titik-titik yang telah dispesifikasikan sebelumnya tanpa satu kali pun bertemu dengan musuh. Titik-titik dalam labirin yang harus dilewati oleh Win Start $L a$ digambarkan sebagai makanan Win Start La

\section{Algoritma Greedy}

Persoalan karakter musuh Win Start La dalam menentukan arah mana yang harus dijalaninya untuk semakin mendekatkan 
dirinya kepada karakter Win Start La dapat dikategorikan sebagai persoalan optimasi, dan persoalan optimasi cukup efektif dipecahkan dengan menggunakan algoritma Greedy.

Persoalan optimasi pada musuh Win Start La ini termasuk persoalan minimasi, yaitu mencari rute terpendek saat ini dari posisi karakterk musuh ke posisi karakter Win Start La.

\section{Android}

Android adalah sistem operasi berbasis Linux yang dipergunakan sebagai pengelola sumber daya perangkat keras, baik untuk ponsel, smartphone dan juga PC tablet. Secara umum Android adalah platform yang terbuka (Open Source) bagi para pengembang untuk menciptakan aplikasi mereka sendiri untuk digunakan oleh berbagai piranti bergerak (Ardiansyah, 2011).

\section{PERANCANGAN SISTEM}

tahapan project planning dan tahap analisa , tahap design, dan tahap input dan output serta fitur game Win Start $\mathrm{La}$ berbasis Android. Dengan adanya metodologi penelitan ini diharapkan dapat memberikan petunjuk dalam merumuskan masalah penelitian.

\section{Use Case Diagram}

Blok diagram disajikan dalam bentuk UML Use Case Diagram. Struktur menu pada aplikasi game Win Start La dirancang khusus pada platform android menggunakan Unity dengan media interaktif.

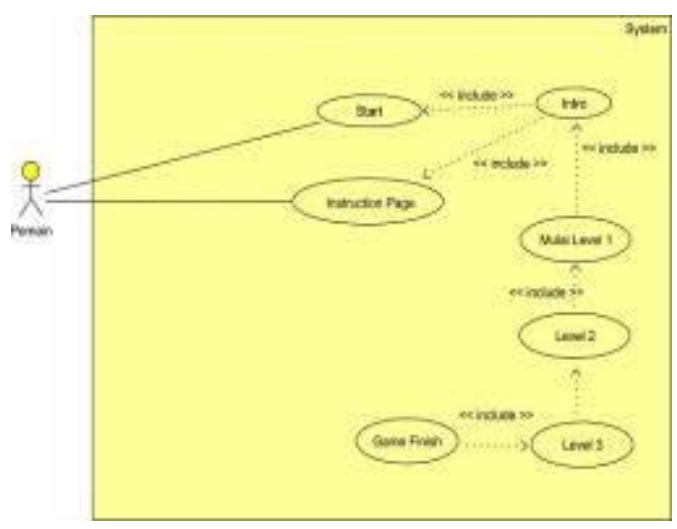

Gambar 1 Use Case Diagram Aplikasi
Skenario pada diagram use case berisi tentang kejadian 'flow if event' use case utama. Di dalamnya menjelaskan urutan interaksi antara aktor dengan use case tersebut dari awal sampai akhir

\section{Activity Diagram}

Diagram ini berisi penjelasan secara lengkap mengenai urutan aktivitas yang terjadi dengan aplikasi Win Start La.

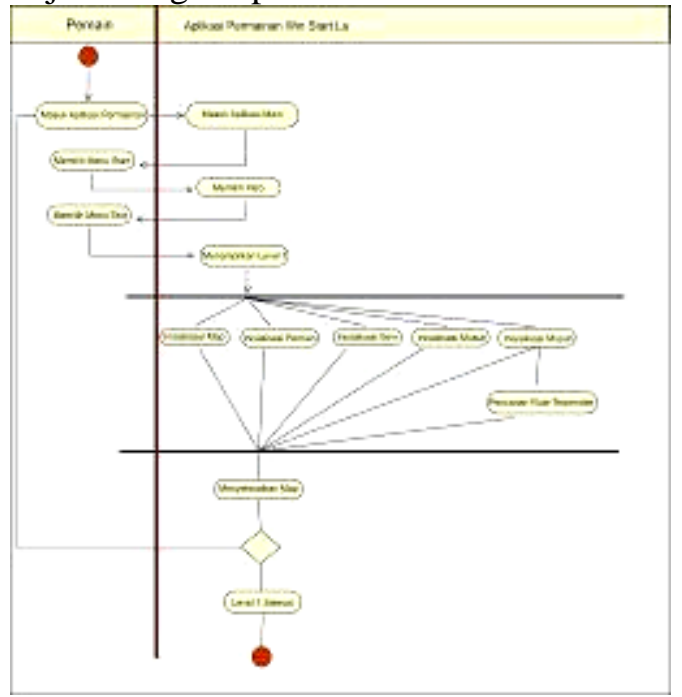

Gambar 2 Diagram Activity Level 1

Proses ini terjadi saat permainan di jalankan. Sistem akan menampilkan arena permainan dimana pemain dapat langsung memainkan level 1 dan menyelesaikan misi permainan pada level 1 , apabila misi tidak terselesaikan maka pemain kembali ke permainan level 1 lagi

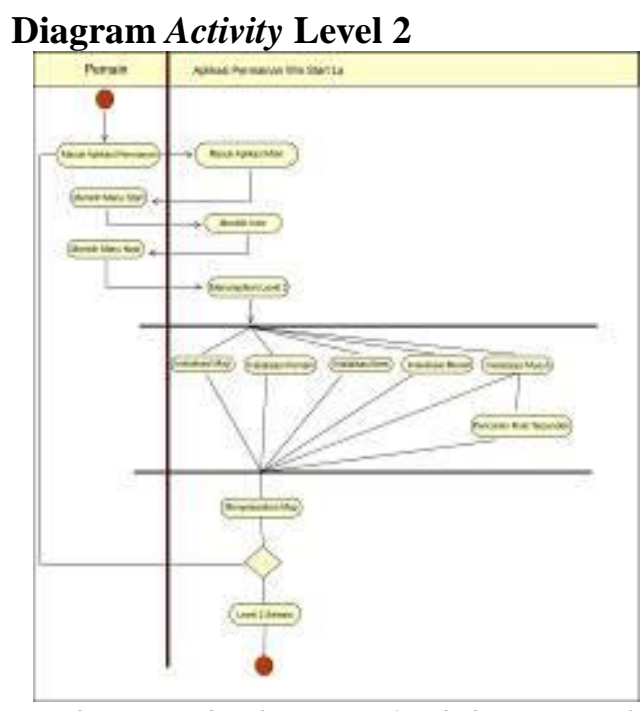

Diagram 3 Diagram Activity Level 2 
Sistem akan menampilkan arena permainan level 2 dan pemain harus menyelesaikan misi permainan pada level 2, apabila misi permainan tidak terselesaikan makapemain akan memulai permainan dari level 1 .

\section{Diagram Activity level 3}

Proses ini terjadi saat pemain telah menyelesaikan palikasi permainan Win Start La pada level 3.

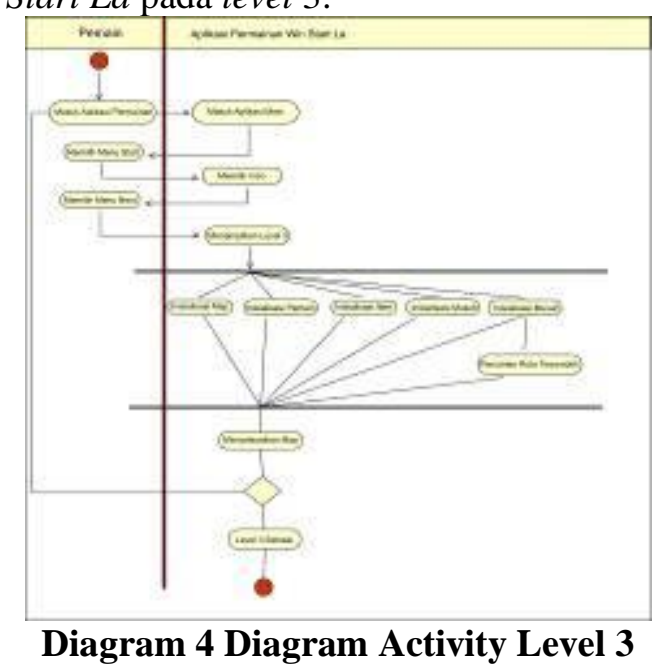

Sistem akan menampilkan arena permainan level 3 dan pemain harus menyelesaikan misi permainan pada level 3, apabila misi permainan tidak terselesaikan maka pemain akan memulai permainan dari level 1 .

\section{Desain Sequence Diagram}

Berikut merupakan diagram sequence yang terdapat pada aplikasi permainan Win Start La berdasarkan use case yang ada.

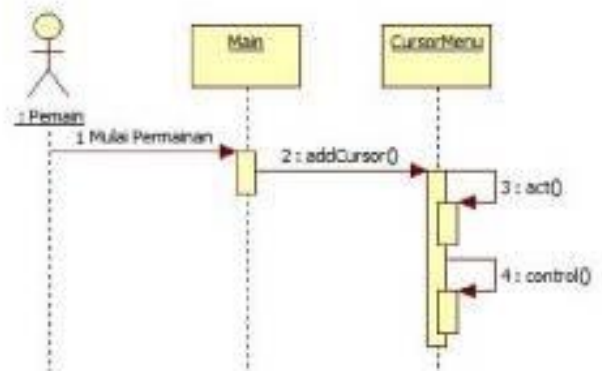

Gambar 5 Diagram Sequence untuk Use Case main

Pada Diagram Sequence seperti yang ditunjukkan pada gambar 5 user pada layar utama ketika mulai bermain maka pemain diminta untuk memilih salah satu menu yang ada di layar utama dan ketika salah satu menu sudah terpilih maka selanjutnya focus akan diarahkan pada menu yang terpilih dan kemudian aksi akan dijalankan sesuai dengan menu terpilih dan selanjutnya aksi yang sudah diaktifkan akan memanggil control yang diberlakukan pada aksi yang terpilih.

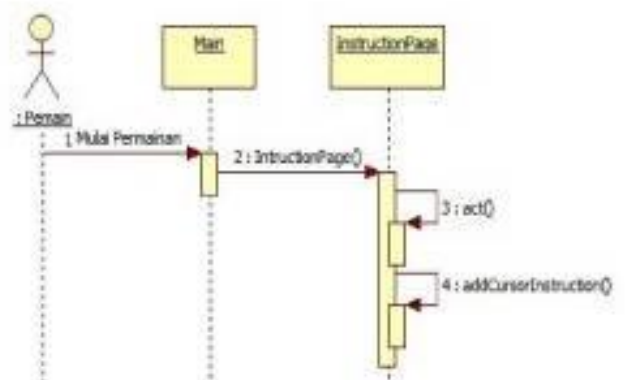

Gambar 6 Diagram Sequence untuk Use Case instructions page

Pada diagram sequence utama seperti yang ditunjukkan oleh gambar 6 pemain apabila mengaktifkan menu instruction maka akan ditampilkan halaman instruction dan pada saat yang bersamaan akan diaktifkan pula aksi yang diberlakukan pada halaman instruction yang selanjutnya focus akan diarahkan sepenuhnya pada control halaman instruction.

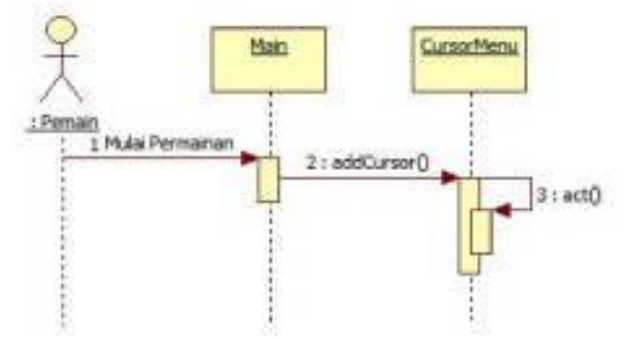

Gambar 7 Diagram Sequence

Pada diagram sequence start seperti yang ditunjukkan gambar 7 pemain memainkan game dan layar utama akan dimunculkan kemudian focus akan diarahkan pada menu yang ada dan apabila salah satu menu diaktifkan maka focus akan diarahkan pada aksi yang diberlakukan pada menu yang sedang aktif. 


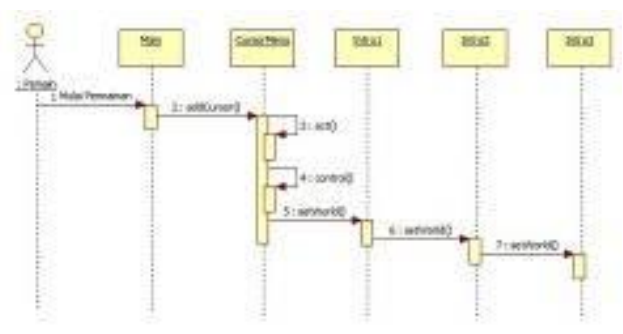

Gambar 8 Diagram Sequence untuk use case intro

Pada diagram sequence intro ketika pemain sudah memainkan game selanjutnya focus akan diarahkan ke salah satu intro yang ada dan pada candela utama intro tersebut terdapat aksi yang berfungsi untuk berpindah antar intro yang ada.

\section{PEMBAHASAN}

\section{Menu Utama}

Ketika pertama kali menjalankan game maka user akan disuguhkan tampilan menu utama seperti gambar 9 berikut ini:

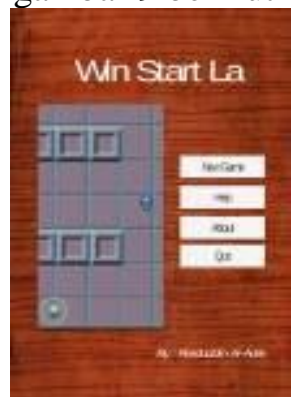

\section{Gambar 9 Menu Utama}

Dan untuk memulai permainan yang perlu dilakukan oleh user adalah mentap tombol New Game dan selanjutnya user akan dibawa menuju menu permainan seperti yang ditunjukkan gambar 10 berikut :

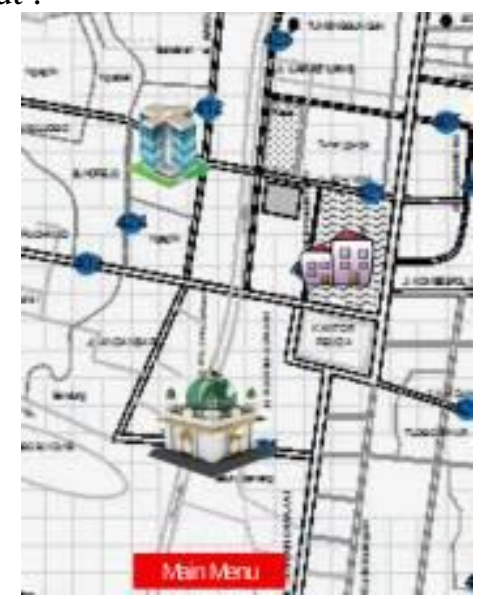

Gambar 10 Menu Game
Dan untuk mulai bermain user bisa mendrag tombol Virtual Joystick seperti yang ditunjukkan oleh anak panah pada Gambar 11 di ataske arah manapun untuk menggerakkan player ke segala arah hingga player bisa bertabrakan dengan salah satu kotak target yang dilindungi oleh musuh.

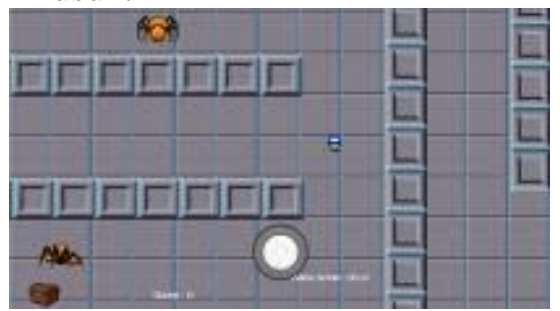

\section{Gambar 11 Tampilan Game Level 1}

\section{Perolehan Skor}

User akan mendapat skor sebesar 25 setiap kali berhasil mencapai box target yang dilindungi oleh musuh setelah berhasil menjawab pertanyaan kuis yang muncul dengan benar dan waktu masih tersedia dan nilai maksimal yang bisa didapat oleh user adalah 100 .

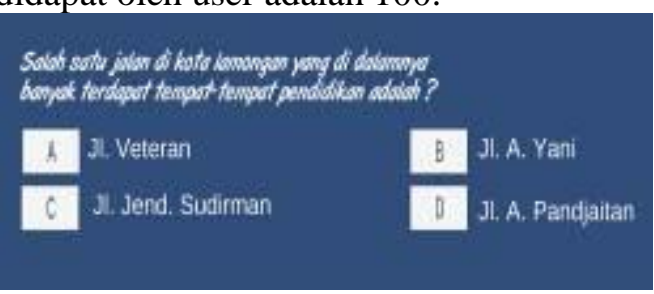

Gambar 12 Tampilan Quiz

\section{Jumlah Quiz}

Total jumlah quiz dari masing-masing level dalam game ini adalah 4 buah quiz yang mana masing-masing quiz bernilai 25 sehingga apabila user bisa menjawab semua quiz dengan benar maka user akan mendapat nilai 100 dan apabila nilai sudah mencapai 100 maka berarti sudah menuntaskan sebuah level dan gambar 4.6 berikut menunjukkan pernyataan bahwa sebuah level sudah berhasil dituntaskan oleh user.

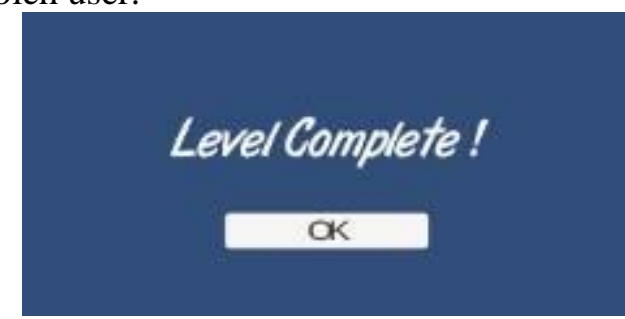

Gambar 13 Tampilan leve 


\section{Reset Game}

Apabila dalam permainan player ternyata bertabrakan dengan musuh yang menjaga kotak target maka game akan dimulai dari awal lagi dengan terlebih dahulu akan dimunculkan sebuah layar yang memberitahu bahwa player telah bersentuhan dengan musuh ( Gambar 4.11 ) sehinnga point yang sudah didapatkan oleh player akan menjadi nol lagi.

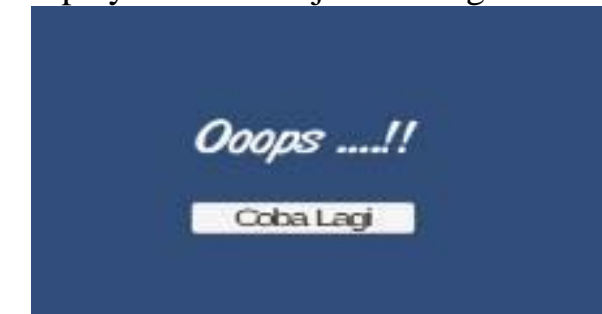

Gambar 14 Tampilan ketika terjadi collide antara player dan musuh

\section{Waktu Game}

Waktu yang disediakan bagi user dalam permainan Win Start La ini berbeda-beda dalam setiap levelnya. Untuk level mudah ( level untuk menguji pengetahuan tentang hal-hal yang berhubungan dengan pendidikan di kota Lamongan ) waktu yang disediakan untuk meuntaskan level ini adalah 3 menit sedangkan untuk level menengah ( level untuk menguji pengetahuan tentang hal-hal yang berhubungan dengan masalah kesehatan di kota Lamongan ) disediakan waktu selama 2 menit untuk menuntaskan semua tantangan yang ada di level menengah ini dan untuk level sulit ( level untuk menguji pengetahuan tentang hal-hal yang berhubungan dengan dunia keagamaan di Kota lamongan ) disediakan waktu selama 1 menit untuk menyelesaikan semua tantangan dalam level ini.

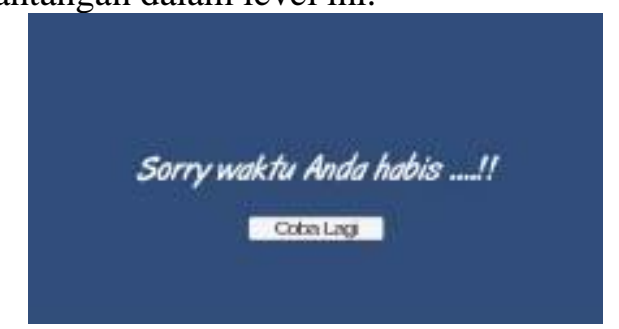

Gambar 15 Tampilan ketika waktu habis

\section{KESIMPULAN}

kesimpulan

Kesimpulan yang dapat diambil dari semua proses yang telah dilakukandalam membangun aplikasi game edukasi ini adalah sebagai berikut:

1. Game Edukasi Win Start La dapat dijadikan sebagai media pembelajaran yang interaktif yang mampu menarik perhatian dan minat anak-anak maupun orang dewasa.

2. Game edukasi yang telah dibangun dapat menciptakan pola pembelajaran tentang pengenalan kota Lamongan yang menarik bagi anak-anak dan orang dewasa dan dapat meningkatkan minat, kecerdasan, kreatifitas dan kemampuan belajar geografi kota lamongan.

\section{Daftar Pustaka}

[1] Acosta, Joan. 2007. World Game and Puzzle. Creative Commons Cannadian

[2] Aldrich, Clark. 2009. Learning Online with Games, Simulations, and Virtual Worlds: Strategies for Online Instruction. Jossey-Bass: San Francisco. 134 pages. ISBN 978-0470-43834-3

[3] Ardiansyah, F. 2011. Pengenalan Android Programming. Depok: Biraynara

[4] Chowanda, A dan Dewi, L, Citra. 2013. Perancangan Game Casual Bertemakan Indonesia Berbasis Android. BINUS University

[5] Latief, Nurul M. 2013. Training Monitoring System for Cyclist Based on Android Application Development. Department of Communication Engineering, Faculty of Electrical Engineering, Universiti Teknologi Malaysia

[6] Nazruddin, Safaat H. 2012. Pemrograman Aplikasi Mobile Smartphone dan Tablet PC Berbasis Android. Informatika

[7] Nikensasi, P. Kuswardayan, I dan Sunaryono, D. 2012. Rancang Bangun Permainan Edukasi Matematika dan Fisika dengan Memanfaatkan Accelerometer dan Physics Engine Box2d pada Android. Jurnal Teknik ITS Vol. 1, (Sept, 2012) ISSN: 23019271 